\title{
Efektivitas Pembelajaran Online Mata Kuliah Filsafat Pendidikan Menggunakan Google Classroom di Masa Pandemi Covid-19
}

\author{
Metoddyus Tri Brata Role ${ }^{1}$, Apri Kurniawan ${ }^{2}$, Theresia Yovita Cendana Sari ${ }^{3}$ \\ ${ }^{123}$ Sekolah Tinggi Agama Katolik Negeri Pontianak \\ ${ }^{1}$ metoddyusrole85@gmail.com
}

\begin{abstract}
This research was conducted to test the effectiveness of online learning using google classroom in terms of student achievement and independence. This research is a quasi experimental study with the one group pretest posttest design. The research was conducted in the Educational Philosophy course, students were given a pretest of learning achievement and learning independence before learning was carried out using google classroom. After being given treatment, students were measured their learning achievement and independence. Learning achievement was measured using tests, while student independence was measured using independence questionnaires. After being measured, the data were analyzed. Learning is said to be effective if (1) the average student learning achievement score is more than 63 and the student independence score is more than 70, (2) more than 75\% of students who get a minimum grade of $B$ and enter the high criteria for student learning independence, and (3) the average posttest score is better than the pretest both for learning achievement and learning independence. Criteria (1) used the one sample t test, criteria (2) used the proportion test, while for criteria (3) used the paired sample t test. After analyzing data, online learning using google classroom is said to be effective in terms of learning achievement but not effective in terms of student independence.
\end{abstract}

Keywords: Effectiveness; Google Classroom; Online Learning; Learning Achievement; Independence Learning

Penelitian dilakukan untuk mengetahui efektifitas pembelajaran online menggunakan google classroom ditinjau dari prestasi belajar dan kemandirian mahasiswa. Penelitian dilaksanakan dalam mata kuliah Filsafat Pendidikan, mahasiswa diberikan pretest prestasi belajar dan kemandirian belajar sebelum dilakukan pembelajaran menggunakan google classroom. Setelah diberikan perlakuan, mahasiswa diukur prestasi belajar dan kemandiriannya. Prestasi belajar diukur dengan menggunakan tes, sedangkan kemandirian mahasiswa diukur menggunakan angket kemandirian. Setelah diukur kemudian data dianalisis. Pembelajaran menggunakan google classroom disebut efektif apabila (1) nilai rata-rata prestasi belajar mahasiswa lebih dari 63 dan skor kemandirian mahasiswa lebih dari 70, (2) lebih dari 75\% mahasiswa yang mendapat nilai minimal B dan masuk kriteria tinggi untuk kemandirian belajar mahasiswa, dan (3) rata-rata nilai posttest lebih baik daripada pretest baik untuk prestasi belajar maupun kemandirian belajar. Setelah dilakukan pengujian data, pembelajaran online menggunakan google classroom efektif dilihat dari prestasi belajar tetapi dilihat dari kemandirian belajar mahasiswa menunjukkan hasil yang tidak efektif.

Kata Kunci: Efektivitas; Google Classroom; Pembelajaran Online; Prestasi Belajar; Kemandirian 


\section{Pendahuluan}

Pada tahun 2020 dunia mengalami musibah, yaitu adanya pandemi Covid-19. Pandemi ini cukup membahayakan karena orang yang terkena dapat mengalami gejala seperti sesak nafas, demam, batuk, dan dapat menyebabkan kematian. Selain itu, Covid19 penyebarannya terbilang cepat dan mudah sehingga penanganannya cukup sulit. Salah satu cara ampuh yang dilakukan untuk menekan penyebarannya adalah dengan menghindari kerumunan dan saling menjaga jarak. Upaya pencegahan melalui penerapan menjaga jarak atau social distancing menimbulkan banyak perubahan dalam berbagai aspek kehidupan termasuk pembelajaran. Biasanya pembelajaran dilakukan dengan cara tatap muka, malah tidak dianjurkan dalam situasi pandemi ini. Untuk itu perlu adanya alternatif lain dalam melaksanakan pembelajaran. Alternatif platform pembelajaran yang dapat dipilih yaitu google classroom.

Google classroom merupakan besutan Google yang bersifat gratis sehingga dapat digunakan baik oleh pendidik maupun mahasiswa untuk melakukan pembelajaran melalui kelas virtual (Muslik, 2019). Pengajar dapat memberikan materi, penugasan, penilaian, dan umpan balik secara langsung, sedangkan mahasiswa dapat mengakses materi, mengerjakan tugas, serta mendapat masukan dari pengajar. Google classroom memiliki beberapa kelebihan seperti yang diungkapkan oleh Dicky dalam (Utami, 2019), (1) mudah digunakan karena dosen dapat memasukkan mahasiswa secara langsung ataupun membagikan kode untuk bergabung (2) hemat waktu, dosen dapat membuat, memeriksa, dan menilai tugas dari mahasiswa secara langsung (3) meningkatkan pengarsipan, karena semua tugas, nilai berada di satu tempat (4) meningkatkan interaksi, dosen dan mahasiswa dapat berdiskusi secara langsung (5) penggunaan google classroom tanpa mengeluarkan biaya dan tanpa iklan sehingga relatif lebih aman digunakan.

Pembelajaran online memerlukan kemandirian dari mahasiswa untuk belajar secara mandiri. Kemandirian belajar menurut Livingston (2012) yaitu proses belajar dimana belajar dengan kemauan sendiri. Sedangkan Aini dan Taman (2012) mendefenisikan kemandirian belajar adalah kemampuan siswa untuk aktif belajar dalam rangka menguasai materi tertentu dengan berbekal pengetahuan yang sudah ada. Walaupun pembelajaran dilakukan secara online, mahasiswa diharapkan tetap belajar secara mandiri. Pembelajaran online tidaklah mudah untuk dilakukan, salah satu permasalahan yang dihadapi adalah koneksi internet (Annur \& Hermansyah, 2020). Hal ini menjadi kendala tersendiri karena mayoritas mahasiswa STAKat Negeri Pontianak merupakan mahasiswa yang berasal dari daerah. Sinyal internet terkadang sering hilang ataupun harus mencari tempat yang terkadang jauh dari tempat tinggal mereka untuk mendapatkan sinyal internet.

Pembelajaran online tidak boleh menjadi alasan penghambat pembelajaran. Prestasi belajar mahasiswa juga harus tetap dijaga. Penelitian terkait pelaksanaan pembelajaran menggunakan google classroom pernah dilaksanakan oleh Sabran dan Sabara (2019) dengan hasil kesimpulan yaitu penggunaan google calssroom cukup efektif digunakan sebagai media pembelajaran. Penelitian-penelitian sebelumnya penggunaan google classroom masih disandingkan dengan pembelajaran tatap muka (blended learning) seperti yang dilakukan oleh Setyoko dan Indriaty (2018). Dalam penelitian ini peneliti menggunakan google classroom secara full online dalam melaksanakan perkuliahan Filsafat Pendidikan. Peneliti akan melihat apakah google classroom efektif digunakan dalam pembelajaran online Filsafat Pendidikan ditinjau dari prestasi belajar dan kemandirian mahasiswa. 


\section{Metode}

Populasi dalam penelitian ini terdiri atas 5 kelas. Penelitian mengambil secara acak 1 kelas untuk dijadikan sampel penelitian kelas eksperimen. Pengambilan menggunakan teknik random sampling. Pengambilan dengan cara tersebut memungkinkan karena penentuan kelas dilakukan secara acak, sehingga kemampuan tiap kelas relatif sama atau tidak jauh berbeda antara satu kelas dengan yang lain (Prasetyono, Ramdayana \& Estiningsih, 2020). Setelah dilakukan pengambilan secara acak terpilih PKK 3 yang digunakan sebagai kelas eksperimen. Jumlah mahasiswa kelas eksperimen adalah 39 mahasiswa, tetapi karena ada beberapa mahasiswa yang tidak mengikuti perkuliahan ataupun tidak mengikuti tahapan-tahapan yang semestinya sehingga menyebabkan data tidak lengkap maka data dikeluarkan dari analisis data. Jumlah mahasiswa akhir untuk kelas eksperimen berjumlah 32 mahasiswa. Sebelum dilakukan pembelajaran menggunakan google classroom, mahasiswa diminta mengerjakan tes dan mengisi angket untuk mengetahui posisi awal meraka. Setelah dilakukan perlakuan, mahasiswa diminta mengerjakan tes dan mengisi angket kembali. Penelitian dilakukan secara penuh menggunakan pembelajaran online.

Validitas isi digunakan untuk menguji validitas instrumen tes dan angket pada penelitian ini, tetapi khusus untuk angket ditambah dengan uji korelasi product moment. Validitas isi dilakukan dengan menggunakan expert judgment sedangkan korelasi product moment menggunakan bantuan IBM SPSS Statistics 26. Setelah dilakukan perhitungan didapat 21 pernyataan angket valid dari 30 pernyataan. Jadi dalam penelitian ini hanya menggunakan 21 pernyataan angket kemandirian belajar. Pada penelitian ini instrumen dikatakan reliabel jika minimal memperoleh nilai 0,40 atau masuk ke dalam kategori reliabilitas cukup. Pada uji reliabilitas, hanya item yang valid saja yang dihitung. Hasil analisis menunjukkan reliabilitas angket kemandirian mahasiswa adalah 0,714. Dari nilai reliabilitas tersebut dapat disimpulkan apabila instrumen reliabel.

\section{Hasil dan Pembahasan}

Untuk menguji efektivitas pembelajaran online menggunakan google classroom maka peneliti menetapkan standar efektivitas. Dalam penelitian ini, penggunaan google classroom dinyatakan efektif dilihat dari prestasi belajar apabila memenuhi kriteria berikut: (1) Nilai rata-rata prestasi belajar mahasiswa lebih dari 63, (2) Lebih dari 75\% mahasiswa yang mendapat nilai minimal B, dan (3) Rata-rata nilai posttest prestasi belajar lebih baik dari nilai rata-rata pretest. Penggunaan google classroom dinyatakan efektif dilihat dari kemandirian belajar mahasiswa apabila memenuhi kriteria berikut: (1) Skor kemandirian mahasiswa lebih dari 70, (2) Lebih dari 75\% mahasiswa yang masuk kriteria tinggi untuk kemandirian belajar mahasiswa, dan (3) Rata-rata skor posttest kemandirian mahasiswa lebih baik dari skor rata-rata pretest. Sebelum uji hipotesis, data prestasi belajar dan kemandirian belajar dideskripsikan terlebih dahulu. Adapun deskripsi data dapat dilihat pada tabel 1 berikut.

Tabel 1. Deskripsi Data Prestasi dan Kemandirian Belajar

\begin{tabular}{lcccc}
\hline \multirow{2}{*}{ Deskripsi } & \multicolumn{2}{c}{ Prestasi Belajar } & \multicolumn{2}{c}{ Kemandirian Belajar } \\
\cline { 2 - 5 } & Pretest & Posttest & Pretest & Posttest \\
\hline Nilai/ Skor rata-rata & 72,50 & 77,75 & 71,22 & 77,47 \\
\hline Standar deviasi & 6,37 & 6,44 & 10,14 & 8,20 \\
\hline Nilai/ Skor maksimum & 85 & 90 & 97 & 90 \\
\hline Nilai/ Skor minimum & 60 & 61 & 53 & 60 \\
\hline Nilai/ Skor maksimum ideal & 100 & 100 & 105 & 105 \\
\hline Nilai/ Skor minimum ideal & 0 & 0 & 21 & 21 \\
\hline
\end{tabular}


Berdasarkan tabel 1 maka terlihat nilai rata-rata prestasi belajar mahasiswa lebih dari 63 baik untuk nilai pretest maupun posttest. Setelah diberi perlakuan terlihat terdapat kenaikan nilai dari sebelum perlakuan mendapatkan nilai rata-rata 72,50 sedangkan setelah diberi perlakuan meningkat menjadi 77,75. Skor kemandirian belajar terlihat pada Tabel 1 lebih dari 70 baik untuk skor pretest maupun posttest. Setelah diberi perlakuan terlihat bahwa rata-rata skor kemandirian belajar mahasiswa meningkat dari sebelum diberi perlakuan 71,22 menjadi 77,47 setelah diberi perlakuan.

Setelah pemberian perlakuan menggunakan google classroom, terlihat kenaikan kemandirian belajar mahasiswa. Mahasiswa terbiasa belajar mengikuti instruksi yang diberikan, mengerjakan tugas, serta berdiskusi. Hal ini seperti penelitian yang dilakukan oleh Salam (2020) dimana mahasiswa mendapatkan beberapa manfaat dari penggunaan google classroom seperti mendapat umpan balik dari tugas yang dikerjakan serta dapat berinteraksi dengan dosen. Dalam penelitian ini menggunakan sampel untuk dilakukan eksperimen, karena itu supaya dapat digeneralisasi maka analisis data menggunakan uji statistika. Pertama dilakukan pengujian untuk menentukan efektivitas penggunaan google classroom ditinjau dari prestasi belajar. Untuk menguji kriteria keefektifan nomor 1 digunakan uji one sample t test. Perhitungan dilakukan berbantuan IBM SPSS Statistics 26. Setelah dilakukan perhitungan didapat nilai sig. $0,00<0,05$, artinya nilai rata-rata prestasi belajar mahasiswa lebih dari 63 terpenuhi. Nilai rata-rata prestasi belajar mahasiswa adalah 77,75 yang secara deskriptif memang jauh lebih tinggi dari nilai yang ditetapkan sebagai batas kriteria ketuntasan dalam penelitian yaitu 63. Berdasarkan uji yang dilakukan maka dapat ditarik kesimpulan jika kriteria keefektifan nomor 1 ditinjau dari prestasi belajar terpenuhi.

Untuk menguji kriteria keefektifan nomor 2 digunakan uji proporsi. Perhitungan menggunakan bantuan program Ms. Excel. Setelah dilakukan perhitungan diperoleh nilai $z_{\text {hitung }}=2,86$ sedangkan $\quad z_{5 \%}=1,645$, karena $z_{\text {hitung }}=2,86>1,645$ artinya tolak $H_{0}$ yang secara statistik artinya mahasiswa yang mendapat nilai minimal B lebih dari $75 \%$. Secara deksriptif mahasiswa yang mendapat nilai B mencapai 96,87\%, jauh lebih tinggi dari nilai yang digunakan sebagai batas dalam penelitian ini yaitu $75 \%$. Berdasarkan uji proporsi maka dapat disimpulkan bahwa kriteria keefektifan nomor 2 ditinjau dari prestasi belajar yaitu lebih dari $75 \%$ mahasiswa yang mendapat nilai minimal B terpenuhi. Untuk menguji kriteria keefektifan nomor 3 digunakan uji paired sample t test. Perhitungan dilakukan berbantuan IBM SPSS Statistics 26. Setelah dilakukan perhitungan diperoleh nilai sig. $=0,00<0,05$. Kesimpulannya adalah tolak $H_{0}$ yang artinya pembelajaran online menggunakan google classroom dikatakan efektif dilihat dari prestasi belajar. Dilihat dari nilai rata-rata prestasi belajar, nilai posttest lebih tinggi dari nilai pretest yaitu 77,75 berbanding dengan 72,50. Setelah dilakukan uji maka dapat disimpulkan jika kriteria keefektifan nomor 3 terpenuhi.

Pembelajaran menggunakan google classroom dikatakan efektif ditinjau dari prestasi belajar apabila ketiga kriteria keefektifan terpenuhi semuanya. Berdasarkan uji statistik dapat diketahui bahwa ketiga kriteria keefektifan sudah terpenuhi semuanya. Artinya google classroom efektif digunakan dalam pembelajaran online Filsafat Pendidikan ditinjau dari prestasi belajar. Penggunaan google classroom dalam perkuliahan Filsafat Pendidikan dapat dikatakan berhasil. Hal ini melihat pada kelebihan yang ada pada google classroom. Hakim (2016) mengatakan kelebihan platform google classroom yaitu pengajar bisa membuat tugas atau materi pembelajaran kemudian membagikannya kepada mahasiswa secara paperless. Menurut Pratama dan Sopryadi (2016) kelebihan google classroom antara lain penyiapan yang mudah, hemat waktu, meningkatkan pengorganisasian, meningkatkan komunikasi, terjangkau dan aman. 
Selanjutnya dilakukan pengujian untuk menentukan efektivitas penggunaan google classroom ditinjau dari kemandirian belajar. Untuk menguji kriteria keefektifan nomor 1 digunakan uji one sample t test. Uji dilakukan berbantuan program IBM SPSS Statistics 26. Setelah dilakukan perhitungan didapat nilai sig. $0,00<0,05$, artinya skor rata-rata kemandirian belajar mahasiswa lebih dari 70. Secara deskriptif mendapatkan rata-rata skor untuk kemandirian adalah 77,47 lebih tinggi dari skor rata-rata yang ditetapkan sebagai batas kriteria ketuntasan dalam penelitian yaitu 70. Berdasarkan uji yang dilakukan dapat ditarik kesimpulan bahwa kriteria keefektifan nomor 1 ditinjau dari kemandirian belajar terpenuhi.

Untuk menguji kriteria keefektifan nomor 2 digunakan uji proporsi. Perhitungan menggunakan bantuan program Ms. Excel. Setelah dilakukan perhitungan diperoleh nilai $z_{\text {hitung }}=0$ sedangkan $\quad z_{5 \%}=1,645$, karena $z_{\text {hitung }}=0<1,645$ maka terima $H_{0}$ artinya secara statistik mahasiswa yang masuk ke dalam kategori tinggi kurang dari atau sama dengan $75 \%$. Secara deksriptif mahasiswa yang termasuk kategori tinggi dalam kemandirian belajar adalah $75 \%$. Walaupun secara deskriptif mencapai $75 \%$ tetapi karena perhitungan menggunakan sample maka yang digunakan adalah analisis menggunakan uji statistik. Berdasarkan uji proporsi maka dapat disimpulkan bahwa kriteria keefektifan nomor 2 ditinjau dari kemandirian belajar tidak terpenuhi. Untuk menguji kriteria keefektifan nomor 3 digunakan uji paired sample t test. Setelah dilakukan perhitungan diperoleh nilai sig. $=0,000<0,05$. Kesimpulannya terima $H_{1}$ yang artinya penggunaan media pembelajaran google classroom efektif ditinjau dari kemandirian belajar. Dilihat dari skor rata-rata kemandirian belajar, skor posttest lebih tinggi dari skor pretest yaitu 77,47 berbanding dengan 71,22. Setelah dilakukan uji dapat ditarik kesimpulan bahwa kriteria keefektifan nomor 3 terpenuhi.

Pembelajaran menggunakan google classroom dikatakan efektif ditinjau dari kemandirian belajar apabila ketiga kriteria keefektifan terpenuhi semuanya. Berdasarkan uji statistik dapat diketahui bahwa kriteria keefektifan nomor 1 dan 3 terpenuhi, sedangkan kriteria keefektifan nomor 2 tidak terpenuhi. Karena ada satu kriteria keefektifan yang tidak terpenuhi maka dapat ditarik kesimpulan yaitu google classroom tidak efektif digunakan dalam pembelajaran online Filsafat Pendidikan ditinjau dari kemandirian belajar. Penggunaan google classroom yang terhitung mudah dan sederhana menjadi salah satu yang menyebabkan penggunaannya efektif untuk digunakan sebagai perkuliahan online semasa pandemi covid-19 ini. Menurut Sukmawati dan Nensia (2019) google classroom dapat menjadikan siswa lebih fokus dalam mengikuti pembelajaran. Hal ini dikarenakan tugas dalam google classroom terdapat deadline, kemudian siswa juga mudah untuk submit tugas karena mereka dapat melakukannya lewat handphone. Dengan kemudahan yang diberikan oleh google classroom, pembelajaran menggunakan google classroom efektif digunakan untuk pengganti perkuliahan tatap muka. Hal ini sesuai dengan penelitian dari Shaharanee, Jamil, dan Rodzi (2014) yang menunjukkan bahwa kebanyakan siswa puas dengan digunakannya google classroom.

Kemudahan dan efektivitas google classroom yang digunakan sebagai platform pembelajaran menjadikan google classroom cukup efektif untuk digunakan dalam pembelajaran online dilihat dari prestasi belajar. Hal ini terlihat dari jumlah mahasiswa yang mendapatkan nilai minimal $\mathrm{B}$ atau lebih dari 63 mencapai 31 mahasiswa dari 32 mahasiswa atau 96,87\%. Sehubungan dengan pembelajaran menggunakan google classroom ditinjau dari prestasi belajar, juga dikemukakan oleh Darmawan dan Ariyanto (2019). Dari hasil penelitiannya terjadi peningkatan prestasi belajar melalui beberapa siklus. Sebelum perlakuan siswa yang mencapai KKM hanya sebesar $48 \%$, setelah 2 siklus meningkat menjadi $89 \%$. 
Beberapa hal yang menjadi kebaruan dalam penelitian ini dibandingkan dengan penelitian. Darmawan dan Ariyanto (2019) dapat dilihat dalam tiga hal. Pertama, terletak pada jenis penelitian. Penelitian ini menggunakan penelitian eksperimen (kuantitatif), sedangkan penelitian Darmawan dan Ariyanto menggunakan Penelitian Tindakan Kelas (PTK). Kedua, variabel prestasi belajar yang diteliti digunakan untuk menguji apakah google classroom efektif digunakan dalam pembelajaran online, sedangkan Darmawan dan Ariyanto menggunakan google classroom untuk meningkatkan prestasi belajar. Ketiga, perbedaan terletak pada subjek, objek, dan lokasi. Dalam penelitian ini, subjek yang diteliti adalah mahasiswa semester 1, objeknya mata kuliah Filsafat Pendidikan dan lokasi di perguruan tinggi. Sedangkan dalam penelitian Darmawan dan Ariyanto, subjek penelitian adalah siswa kelas X IPS, objeknya adalah Matematika, dan lokasinya di SMA 2 Batik Surakarta.

Penggunaan google classroom dalam pembelajaran online ternyata tidak efektif ditinjau dari kemandirian belajar mahasiswa. Menurut Dwi, dkk (2020: 37) yang menjadi hambatan utama pembelajaran online salah satunya yaitu sarana dan prasarana serta ketidaksiapan penggunaan teknologi. Mengingat mahasiswa STAKat Negeri Pontianak yang mayoritas berasal dari daerah, sehingga untuk pembelajaran online memang sulit untuk maksimal karena sinyal di daerah yang kurang stabil dan juga kesiapan mahasiswa untuk beralih dari perkuliahan tatap muka menjadi perkuliahan online secara mendadak. Dari tiga kriteria keefektifan ditinjau dari kemandirian belajar, pembelajaran menggunakan google classroom hanya mampu memenuhi dua kriteria saja, sedangkan satu kriteria yaitu lebih dari $75 \%$ mahasiswa termasuk kategori minimal tinggi untuk kemandirian belajar tidak terpenuhi. Secara data deskriptif mahasiswa yang masuk ke dalam kategori tinggi ada 24 mahasiswa dari 32 mahasiswa atau mencapai tepat $75 \%$, tetapi karena penggunaan analisis data menggunakan data sampel maka analisis statistiklah yang digunakan. Meskipun demikian penggunaan google classroom pada perkuliahan Filsafat Pendidikan dapat dikatakan hampir efektif ditinjau dari kemandirian belajar.

Berdasarkan angket yang sudah dibagikan terdapat satu pernyataan yang memiliki skor paling besar yaitu peryataan "Saya lebih memilih bermain game daripada belajar". Rata-rata skor dalam pernyataan tersebut mencapai 4,5. Artinya hampir semua mahasiswa tidak bermain game untuk menghindari belajar. Mayoritas mahasiswa sudah bagus dalam menentukan prioritas utama. Pernyataan yang paling sedikit skornya adalah pernyataan "Saya mempelajari materi terlebih dahulu sebelum diajarkan". Rata-rata skornya adalah 2,5. Artinya masih sedikit mahasiswa yang mempelajari terlebih dahulu materi sebelum diajarkan atau menunggu diajarkan terlebih dahulu baru dipelajari. Hal ini mencerminkan bahwa kemandirian belajar mahasiswa STAKat Negeri Pontianak memang masih kurang.

Untuk meningkatkan kemandirian belajar mahasiswa, diperlukan proses pembelajaran yang dapat menuntun mahasiswa untuk melatih mereka belajar secara mandiri tanpa harus diminta oleh dosennya untuk belajar terlebih dahulu. Hal ini mengingat bahwa proses pembelajaran lebih penting daripada nilai dalam mengembangkan kemandirian belajar (Red'ko, Yuzhakova, dan Yanushevskaya, 2015). Mengingat bahwa mahasiswa yang mendapatkan pembelajaran Filsafat Pendidikan adalah mahasiswa semester 1, sehingga kebiasaan-kebiasaan di saat SMA mungkin masih terbawa.

\section{Kesimpulan}

Ada dua kesimpulan yang dapat ditarik. Pertama, ada 3 kriteria keefektifan dalam penggunaan google classroom ditinjau dari prestasi belajar. Kriteria tersebut adalah (1) nilai rata-rata prestasi belajar mahasiswa lebih dari 63, (2) lebih dari 75\% mahasiswa 
mendapat nilai minimal $\mathrm{B}$, dan (3) rata-rata nilai posttest lebih baik daripada rata-rata nilai pretest. Semua kriteria keefektifan terpenuhi ditinjau dari prestasi belajar. Maka pembelajaran online Filsafat Pendidikan dengan menggunakan google classroom dinyatakan efektif dilihat dari prestasi belajar. Kedua, terdapat 3 kriteria keefektifan dalam penggunaan google classroom ditinjau dari kemandirian belajar. Kriteria tersebut adalah (1) skor rata-rata kemandirian belajar mahasiswa lebih dari 70, (2) lebih dari $75 \%$ mahasiswa termasuk kedalam kategori minimal tinggi, dan (3) rata-rata skor posttest lebih baik daripada rata-rata skor pretest. Dari ketiga kriteria keefektifan, kriteria nomor 1 dan 3 terpenuhi, tetapi kriteria keefektifan nomor 2 tidak terpenuhi. Penggunaan google classroom dikatakan efektif jika ketiga kriteria tersebut terpenuhi semua, karena ada satu kriteria yang tidak terpenuhi maka penggunaan google classroom ditinjau dari kemandirian belajar tidak efektif dalam pembelajaran online pada mata kuliah Filsafat Pendidikan.

Berdasarkan simpulan hasil penelitian dapat dinyatakan penggunaan google classroom cukup efektif digunakan sebagai alternatif perkuliahan tatap muka yang tidak dapat dilaksanakan di masa pandemi. Penggunaan google classroom dapat juga diterapkan apabila dosen berhalangan hadir karena ada kegiatan lain namun dapat tetap mengajar apabila keadaan sudah menjadi normal. Dalam masa pandemi ini pengajar juga perlu memperhatikan kesulitan mahasiswa dalam melakukan pembelajaran online mengingat banyak mahasiswa yang kesulitan untuk mengakses internet, sehingga penggunaan media Google Classroom bisa menjadi lebih bersahabat karena penggunaannya yang mudah dan hemat kuota dibandingkan dengan penggunaan media lain seperti Zoom ataupun Google Meet.

\section{Daftar Pustaka}

Aini, P.N. \& Taman, A. (2012). Pengaruh Kemandirian Belajar dan Lingkungan Belajar terhadap Prestasi Belajar Akuntansi Siswa Kelas XI IPS SMA N 1 Sewon Bantul. Jurnal Pendidikan Akuntansi Indonesia, X(1), 48-65.

Annur, M.F, \& Hermansyah. (2020). Analisis Kesulitan Mahasiswa Pendidikan Matematika dalam Pembelajaran Daring pada Masa Pandemi COVID-19. Paedagoria : Jurnal Kajian, Penelitian dan Pengembangan Kependidikan, 11(2), 195-201.

Darmawan, Y. \& Ariyanto. (2019). Penggunaan Aplikasi Google Classroom dalam Upaya Meningkatkan Hasil Belajar Matematika pada Siswa Kelas X IPS 3 SMA Batik 2 Surakarta (Skripsi, Universitas Muhamadiyah Surakarta).

Dwi, B., Amelia, A., Hasanah, U., Putra, A.M., \& Rahman, H. (2020). Analisis Keefektifan Pembelajaran Online di Masa Pandemi Covid-19. Mahaguru: Jurnal Pendidikan Guru Sekolah Dasar, 2(1), 28-37.

Hakim, A.B. (2016). Efektifitas Penggunaan E-Learning Moodle, Google Classroom dan Edmodo. I-STATEMENT: Information System and Technology Management, 2(1), 2-6.

Livingston, K. (2012). Independent Learning. Dalam: Seel, N.M. (Eds.), Encyclopedia of the Sciences of Learning. Boston, MA: Springer.

Muslik, A. (2019). Google Classroom sebagai Alternatif Digitalisasi Pembelajaran Matematika di Era Revolusi Industri 4.0. Andragogi: Jurnal Diklat Teknis Pendidikan Dan Keagamaan, 7(2), 246-255.

Prasetyono, H., Ramdayana, I., P, \& Estiningsih, W. (2020). Peningkatan Kinerja Guru SMK melalui Lingkungan Kerja dengan Mengoptimalkan Efektifitas Kepemimpinan dan Komitmen Tugas. JMSP (Jurnal Manajemen dan Supervisi Pendidikan), 4 (3), 255-266. 
Pratama, D. \& Sopryadi, H. (2016). Analisis Pemanfaatan Google Classroom Terhadap Efisiensi Pada STMIK XYZ. In Prosiding Seminar Nasional Teknologi Informasi 2016 (pp. 61-72).

Red'ko, L., Yuzhakova, M., \& Yanushevskaya, M. (2015). Creative Independent Learning for Developing Students' Professional Competencies. Procedia - Social and Behavioral Sciences, 214, 319-324.

Sabran \& Sabara, E. (2019). Keefektifan Google Classroom sebagai media pembelajaran. In Prosiding Seminar Nasional lembaga Penelitian Universitas Negeri Makassar (pp. 122-125)

Salam, U. (2020). The Students' Use of Google Classroom in Learning English. Jurnal Pendidikan Indonesia (JPI), 9(4), 628-638.

Setyoko \& Indriaty. (2018). Implementasi Pembelajaran Blended Learning Berbasis Media Google Classroom Terhadap Hasil Belajar Mahasiswa Pendidikan Fisika. Jurnal Pendidikan Fisika dan Sains, 1(1), 5-10.

Sukmawati, S., \& Nensia, N. (2019). The Role of Google Classroom in ELT. International Journal for Educational and Vocational Studies, 1(2), 142-145.

Shaharani, I.N.M., Jamil, J.M., \& Rodzi, S.S.M. (2014). The Application of Google Classroom as a Tool for Teaching and Learning. Journal of Telecommunication, Electronic and Computer Engineering, 8(10), 5-8.

Utami, R. (2019). Analisis Respon Mahasiswa terhadap Penggunaan Google Classroom pada Mata Kuliah Psikologi Pembelajaran Matematika. In Prosiding Prisma: Prosiding Seminar Nasional Matematika (pp. 498-502). 